\title{
How does cognitive dissonance influence the sunk cost effect? [Corrigendum]
}

Chung SH, Cheng KC. Psychol Res Behav Manag. 2018; 11:37-45

On page 37, Introduction section, $4^{\text {th }}$ sentence reads "Over the past half century, research of the suck cost effect has focused on exploration of probable factors that explain the cause of the sunk cost effect" it should have been "Over the past half century, research of the sunk cost effect has focused on exploration of probable factors that explain the cause of the sunk cost effect".

modification and management; Clinical applications; Business and sports performance management; Social and developmental studies; Animal studies. The manuscript management system is completely online and includes a very quick and fair peer-review system, which is all easy to use. Visit http://www. dovepress.com/testimonials.php to read real quotes from published authors. 